\title{
Религиозные и дипломатические миссии византийских епископов в Сасанидской державе в V-VI вв.
}

\author{
А.О. Куликов \\ Национальный исследовательский \\ Нижегородский государственный университет им. Н.И. Лобачевского, \\ Россия, 603950, г. Нижний Новгород, пр. Гагарина, 23 \\ E-mail: kulickoff.aleksander@gmail.com
}

\begin{abstract}
Аннотация
В данной работе рассматривается феномен религиозного миссионерства, направленного из восточных областей Византии на территорию Сасанидского Ирана. Епископы играли значительную роль не только в проповеди своей религии, но и в политике, выступая в качестве дипломатической силы, налаживающей диалог между соперничающими государствами. Миссионеры зачастую выступали как лидеры тех территорий, которые они представляли, и в общении с сасанидскими царями стремились отстаивать интересы своих земель и защитить свою паству. Западные епископы при общении с епископами Церкви Востока стремились навязать свои представления о христианстве, что особенно ярко проявилось на Селевкийско-Ктесифонском соборе 410 г., когда был принят Никейский символ веры и уменьшены различия в канонах грекоримской церкви и Церкви Востока. Одной из целей религиозных миссий епископов грекоримского (средиземноморского) мира на восток являлся также поиск и сохранение христианских святынь, чем занимался, например, епископ Маруфа Мартиропольский. Кроме того, представители сирийской христианской элиты привозили с собой книги и идеи, которые оказывали влияние на персидский мир. Таким образом, можно сказать, что поездки греческих епископов в Сасанидский Иран были разноплановым и сложным явлением, связанным не только с религией, но также с дипломатией и культурой. Исследование данной проблемы позволяет лучше понять феномен религиозных миграций греческой христианской элиты в другие регионы мира, а также чаяния, потребности и надежды данной части общества Восточно-Римской империи.
\end{abstract}

Ключевые слова: христианство, православие, Церковь Востока, Сасаниды, Византия, Римская Империя, история дипломатии.

Для цитирования: Куликов А.О. 2021. Религиозные и дипломатические миссии византийских епископов в Сасанидской державе в V-VI вв. Via in tempore. История. Политология, 48 (1): 55-64. DOI: 10.52575/2687-0967-2021-48-1-55-64.

\section{Religious and diplomatic missions of the Byzantine Bishops in the Sassanian empire in the $5^{\text {th }}-6^{\text {Th }}$ centuries A. D.}

\author{
Aleksandr O. Kulikov \\ N.I. Lobachevsky State University of Nizhni Novgorod, National Research University, \\ 23 Gagarin Ave., Nizhni Novgorod, 603950, Russia \\ E-mail: kulickoff.aleksander@gmail.com
}

\begin{abstract}
This work studied religious missionary deeds of eastern Byzantine bishops on the territory of Sassanian Iran. Bishops played a significant role not only in the preaching of their religion, but also in politics, acting as a diplomatic force, forging dialogue between rival states. Bishops often acted as the leaders of the territories they represented, and in communication with the Sassanian shahs they sought to defend the interests of their lands and protect their flock. Byzantine bishops, while communicating with the bishops of the Church of the East, sought to impose their ideas about Christianity, which was
\end{abstract}


especially clearly manifested at the Seleucia-Ctesiphon Council in 410 , when the Nicene Creed was adopted and the differences in the canons was reduced. One of the goals of the religious missions of the bishops of the East-Roman (Mediterranean) world to the East was also the search and preservation of Christian relics, which, for example, was done by bishop Marutha of Martyropolis. In addition, the Syrian Christian elite brought with them books and ideas that influenced the Persian world. Thus, the trips of the Greek bishops to Sassanian Iran were a diverse and complex phenomenon associated not only with religion, but also with diplomacy and culture. The study of this issue allows us to better understand the phenomenon of religious migrations of the Greek Christian elite to other regions of the world, as well as the aspirations, needs and hopes of this East Roman Empire social group.

Keywords: Christianity, Orthodoxy, Church of the East, Sassanids, Byzantium, Roman Empire, history of diplomacy.

For citation: Kulikov A.O. 2021. Religious and diplomatic missions of the Byzantine Bishops in the Sassanian empire in the $5^{\text {th }}-6^{\text {Th }}$ centuries A. D. Via in tempore. History and political science, 48 (1): 55-64 (in Russian). DOI: 10.52575/2687-0967-2021-48-1-55-64.

\section{Введение}

Религиозные миссии являлись одной из важнейших особенностей раннесредневековой истории. Проповедники, путешествовавшие по всей позднеантичной ойкумене, несли новые знания, новые идеи и новый взгляд на весь мир практически во всех возможных направлениях. Одним из важнейших направлений путешествий византийских епископов был Средний Восток, а именно - раскинувшиеся на его просторах владения Сасанидов. Эти пространства виделись в качестве перспективных как с точки зрения проповеди, так и с точки зрения политики. Кроме того, западные земли Сасанидской державы, населенные арамеоязычным населением, были культурно и этнически близки населению восточных областей Римской империи, в частности Сирии, что облегчало как проповедь, так и переговорный процесс.

Источники по данной теме представлены в первую очередь христианской религиозной литературой и в меньшей степени литературой светской. Значительное число вопросов, связанных с историей церкви Востока и её связью с церковью средиземноморского региона, можно почерпнуть из Сирийского Восточного Синодикона [Synodicon Orientale, 1902], сборника материалов Ктесифонского собора. Значительная информация содержится в сирийской историографии, одной из самых ярких компиляций которой является «Хроника Сеерта», текст которой был написан на арамейском и затем переведен на литературный арабский. В дальнейшем он был подвергнут редакции Мара Аддая Шера, халдейского архиепископа Сеерта, и опубликован в виде нескольких отрывков с параллельным французским переводом в серии Patrologia Orientalis с 1910 по 1919 г. [Patrologia Orientalis. Tomus 04, 1908; Patrologia Orientalis. Tomus 05, 1910; Patrologia Orientalis. Tomus 07, 1911; Patrologia Orientalis. Tomus 13, 1919]. Другая группа исторических источников представлена византийской историографией и житиями: сочинениями Сократа Схоластика [Patrologia Graeca, T. 67. 1859; Сократ Схоластик, 1996], Прокопия Кесарийского [Чекалова, 1993], Агафия Миринейского [Левченко, 1953] и другими историческими сочинениями, а также агиографической литературой.

Еще одна группа источников связана с персидской и арабо-мусульманской историографией, самыми яркими и полными текстами которой являются сочинения ат-Табари [Bosworth, 1999] и ибн Мискавейха [Emami, 1379 (2001)]. Характерной чертой этой историографической традиции является негативная характеристика тех сасанидских шахов, которые положительно оцениваются в греческой и сирийской историографической традиции. По всей видимости, данная негативная оценка унаследована от ныне утраченной официальной позиции зороастрийского жречества. 
Вопросы, связанные с феноменом религиозного миссионерства и посольств греческих епископов, часто затрагиваются в историографии. Одним из крупных изданий, рассматривавших вопрос истории церкви Востока через призму сирийской историографии, была работа «The Chronicle of Seert. Christian Historical Imagination in Late Antique Iraq» [Wood, 2013], в которой автор рассматривал вопрос религиозных миссий в регионе с точки зрения отражения их в христианской сирийской историографии, в первую очередь - в «Хронике Сеерта».

Вопросы, связанные с ментальностью и идентификацией сирийцев Римской империи, рассмотрены в работе «Сирийцы в греко-римском мире» [Andrade, 2013].

Одной из крупных работ, посвященных непосредственно византийско-персидским культурно-дипломатическим связям, является работа П.К. Меттью «The Two Eyes of the Earth: Art and Ritual of Kingship Between Rome and Sasanian Iran» [Matthew, 2009], в которой была проанализирована история римской-персидских отношений. В работе Уорвика Болла «Rome in the East. The Transformation of an Empire» [Ball, 2000] изучены взаимоотношения римлян с восточными соседями и вассалами, способы и пути влияния друг на друга, а также их результаты. Особое место в этой работе занимает изучение римскоперсидской границы, восточных городов и изменений, происходивших в ней. Монография A. Джиллета «Envoys and Political Communication in the Late Antique West, 411-533» [Gillett, 2003] анализирует роль посольств в период с момента создания первых «варварских королевств» на Западе до эпохи Юстиниана, практики и модели римской императорской дипломатической администрации.

В русскоязычной литературе очерки истории церкви Востока рассматриваются в различных книгах и статьях Н.Н. Селезнева, в частности, в книгах «Ассирийская Церковь Востока. Исторический очерк» [Селезнев, 2001] и «Несторий и Церковь Востока» [Селезнев, 2005]. Политические миссии христианских епископов рассмотрены в статьях и диссертации А.В. Пикина [Пикин, 2016; Пикин, 2016; Пикин, 2018].

Тем не менее проблема политических миссий христианских епископов в Сасанидскую державу на данный момент полноценно не изучена. Многие проблемы остаются недостаточно освещенными.

Целью данной статьи является анализ религиозных миссий и путешествий христианских епископов на территорию Сасанидской державы путём выяснения их специфики, причин, целей, хода, деяний и достигнутых результатов.

\section{Основная часть}

Христианская община в границах Сасанидской державы имеет долгую историю. Первые христиане в регионе появились еще во времена Парфянского царства. Число христиан росло здесь не только за счет естественных социальных причин, таких как проповеди, экономические и культурные связи, этническая близость населения римской Сирии и персидской Местопотамии, но и за счет пленников, пригоняемых персидскими шахами из захваченных римских городов [Мишин, 2014]. Вероятно, пестрый этнический и культурный характер христианского населения Среднего Востока (арамеи, кавказские народы, принявшие христианство персы и согдийцы, угнанное из Римской империи эллинизированное население) оказал решающее влияние на организацию и структуру церкви Ирана. На культурную и религиозную разницу накладывались также огромные расстояния и гористо-пересеченный ландшафт Персии. Долгое время церковь Востока не могла не прийти к единой организации и форме.

Население востока Римской империи - сирийцы - были этнически и культурно близки населению запада Сасанидской державы, в первую очередь северной Месопотамии, которая, по сути, являлась Восточной Сирией. Их особая этническая индивидуальность в рамках единого общеримского имперского пространства [Andrade, 2013] делала Сирию и сирийцев естественным культурным мостом между Римом и Ктесифоном. Роль 
епископов в римской Сирии зачастую усиливалась их особо важной ролью в экономической жизни региона [Пигулевская, 2000, с. 80-82]. Возможно, именно про сирийцев писал Сократ Схоластик, замечая о «частых связях» между римлянами и персами [Patrologia Graeca, T. 67. 1859, p. 751-752; Сократ Схоластик, 1996, с. 273].

Религиозные миссии св. Мария, св. Маруфы Майферкатского в IV-VI вв., а также другие посольства, паломничества и переселения средиземноморских епископов на восток были направлены в первую очередь к этому разобщенному христианскому населению Персии.

Одним из самых первых и ярких примеров проповедников стал сириец св. Марий, живший во II в. и оставивший особо яркий и важный след в истории церкви Востока. Результаты дел, совершенных Марием, можно считать важным вкладом в историю восточного христианства. Согласно поздним (написанным в VI в.) «Деяниям Мария» [Harrak, 2005, p. 110], св. Марий в результате своей проповеди смог обратить в христианство арамеоязычные области в Месопотамии и Ассирии; его религиозная миссия нашла своё завершение в районе Хузистана. Проповедь св. Мария не продвинулась дальше в провинцию Фарс, что является весьма показательным фактом: Хузестан был границей арамеоязычного мира, а за ним, далее на восток, в Фарсе, начинался регион, занятый преимущественно персоязычным населением. По пути Марий столкнулся с христианским населением, обращенными торговцами из Эдессы - города, из которого он сам начал свою миссию [Wood, 2013]. Миссия Мария сумела заложить основы изменений ментальности населения Месопотамии: как замечал сирийский писатель II-III вв. Бардасан Эдесский, христиане стали «новыми людьми», независимыми от языческих обычаев окружавших их народов [Drijvers, 1965, p. 60]. Создавалось новое культурно-религиозное пространство, которое закономерно начало играть важную роль в социальной и политической жизни региона.

Определённую роль в становлении христианской общины Сасанидского Востока сыграли насильственные переселения персами христианских епископов в глубины Сасанидской империи. Например, в 257 г. в город Бет Лапат (Гонди-Шапур) был переселен епископ Димитриан Антиохийский и часть его паствы, что привело к основанию новой епархии [Селезнев, 2001]. Подобная система вносила определённые разногласия: появлялись параллельные церковные структуры местного населения и пригнанных пленников [Селезнев, 2001]. Можно предположить, что средиземноморские пленники привозили с собой новые идеи и книги, которые затем повлияли на развитие персидской философии и науки: чуть позднее Гонди-Шапур стал одним из интеллектуальных центров Среднего Востока, что, как можно предположить, было обеспечено наличием общины пленников из средиземноморского региона.

Роль религиозных проповедников в исследуемую эпоху была велика. Религиозные деятели путешествовали по всему известному миру, проповедуя свое видение христианства по странам и народам. В этом смысле крайне показателен пример проповедника Симеона Бет-Ашамского, который за частую и активную проповедь среди несториан получил характерное прозвище «Спорщик» [Мишин, 2017]. Но при этом стоит понимать, что такую возможность, как использование уважаемых христианских проповедников в политических целях, не могли не использовать государственные власти, а также то, что и сами епископы могли по мере сил и желания участвовать в политической деятельности.

Религиозные миссии проповедника несколько более поздней эпохи, Маруфы Майферкатского, жившего в конце IV - начале V вв., были тесно связаны с временным политическим сближением Рима и Персии в данный исторический период, пришедшийся на эпоху правления шахиншаха Йездигерда.

Начало правления Йездигерда охарактеризовалось расцветом христианства в Иране, что во многом являлось результатом политики самого шаха. Царь приостановил гонения и начал пытаться найти общий язык с христианами, результатом чего стало достаточно лояльное отношение к нему христианских историографов позднего периода 
[Wood, 2013, P. 21]. Греческие христианские авторы также положительно оценивали политику Йездигерда. В рамках данного сближения происходили религиозные и дипломатические миссии Маруфы, епископа Мартиропольского, который посетил шахский двор в 399 г. Судя по всему, Маруфа сумел найти общий язык с сасанидской элитой, что отразилось в источниках: сохранились описания того, как Маруфа творил чудеса, с помощью которых сумел обратить шаха на свою сторону [Brock, 2010, P. 306-311]. Например, Сократ Схоластик описывает, как Маруфа смог разоблачить злые замыслы зороастрийских жрецов, а затем сумел избавить сына царя от мучившего его демона [Patrologia Graeca, T. 67. 1859, p. 753-754; Сократ Схоластик, 1996, с. 274]. Важно отметить, что согласно тексту Сократа Схоластика, Маруфа «лечил» царевича не единолично, а совместно с персидским епископом Авдой, что может являться косвенным отражением реальных попыток Маруфы найти компромисс с месопотамскими христианами.

Деятельность Маруфы получила большое отражение как в сирийской, так и греческой историографии, и обросла множеством сведений разной степени правдоподобности [Пикин, 2018]. Несомненно, лояльность сасанидских властей имела свои границы, но намеков на резкое отторжение со стороны шаха в источниках не имеется. Примечательно, что параллельно в персидской и арабо-мусульманской традиции Йездигерд характеризуется как «гнусный», «грешник», а его деятельность оценивается в сугубо негативных коннотациях, что наиболее подробно отражает «История Пророков и Царей» ат-Табари [Вosworth, 1999, P. 848-854].

Кроме того, одной из политических целей Маруфы, возможно, было достижение договоренностей о легитимизации молодого императора Феодосия путем усыновления его персидским шахом. Данная гипотеза, основанная лишь на поздних сообщениях Прокопия и скептически относящегося Агафия Миринейского, не поддерживается рядом исследователей [Пикин, 2018]. Учитывая полностью религиозную повестку посольств Маруфы, представляется маловероятным обсуждение на них столь серьезного чисто политического вопроса, как усыновление одного государя другим при отсутствии на переговорах представителей византийской светской власти. Если подобные заявления и исходили из Константинополя через Маруфу, то они явно ничем не закончились: процесс усыновления как в римской, так и персидской традиции требовал проведения определенных ритуалов, о проведении которых никаких сведений не имеется [Куликов, Ващева, 2018].

Одним из самых ярких итогов деятельности Маруфы стал созыв церковного собора 410 г. и достижение нескольких договорённостей римлян и персов [Wood, 2013, p. 21]. Кроме того, епископу было позволено вывезти с собой мощи мучеников, пострадавших во время гонений при предыдущих шахах, которые он по приказу византийского императора разместил в «Городе мучеников» Мартирополе [Greatrex, Lieu, 2002, p. 31].

Собор в Ктесифоне также был созван не только с религиозными целями, но и для урегулирования нестабильности на римско-персидской границе. После заключения договора в 399 г. Маруфа совершил визит в 402 г. в контексте переговоров между императором Аркадием (395-408 гг.) и персами. Результатом переговоров стал уклон Йездигерда к религиозной терпимости. Новый визит 409 г. имел целью решение внутренних проблем в месопотамской церкви [Wood, 2013, p. 2].

На церковном соборе закреплялась существующая дипломатическая ситуация. Интересно, что в документах, кроме традиционных славословий в адрес шаха и Исхака, лидера месопотамской церкви, Маруфа упоминается в качестве «посредника мира между Востоком и Западом» [Synodicon, 18-19]. Кроме него зафиксировано присутствие епископов сириоязычных регионов римского мира: Антиохии, Алеппо, Эдессы, Теллы, Амиды, митрополитов Нисибиса, Адиабены, Бет-Гармая, Хузистана, Майшана.

На церковный собор в Ктесифоне Маруфа доставил послания от западных епископов, таких как Порфирий Антиохийский, Акакий Алеппский, Пакида Эдесский, Евсевий Теллский и Акакий Амидский [Селезнев, 2001], представив их в самоличном переводе 
[Пикин, 2018]. В этом письме христиане Сасанидского Ирана призывались к признанию постановлений Никейского собора и Никейского символа веры, единоообразию в календаре и упорядочиванию системы управления религиозными епархиями. В рамках планируемого сближения двух церквей произошел визит на территорию Восточной Римской империи католикоса Мар Ябалаха I в 417/18 г., целью которого было заключение «мира и примирение двух империй» [Greatrex, Lieu, 2002, p. 36]. В «Хронике Сеерта» сообщается, что епископ Ябаллаха был выбран для дипломатических переговоров с римлянами после приема посольства Акакия Амидского, в ходе которых получил подарки от Феодосия II, которые были затем были использованы для строительства и восстановления церквей [Wood, 2013, p. 35].

Через несколько лет, в 419/20 г., епископ Акакий Амидский присутствовал на втором соборе Персидской церкви в городе Вех-Ардашире. Второй визит Акакия в 420 г. был приурочен к созыву вышеупомянутого собора, на котором епископ прочитал приветственное письмо и предложил персидским христианам принять каноны средиземноморской церкви.

Таким образом, дипломатические миссии епископов стали источником для получения пожертвований от византийской церкви и явились дипломатическим, культурным и религиозным мостом между Империей и Сасанидским Ираном, Церковью Константинополя и Церковью Востока. Организация католикосата, организация церковных соборов и культ мучеников в начале V в. во многом были определены влиянием римсковизантийской церкви и её представителей.

Сближение византийского и восточного христианства начало терять темпы после загадочной смерти шаха Йездигерда, погибшего при невыясненных обстоятельствах. Новый правитель, Бахрам V Гур (420-439 гг.), начал вести активную антиримскую и антихристианствую политику. Однако и в этот период связи не угасают полностью.

Позднее, в конце VI в., в этом процессе также участвовал епископ Мелитинский Дометиан, посланный императором для решения вопроса помощи принцу Хосрову, будущему Хосрову II Парвизу. Как писал по этому поводу Феофан: «В этом году (т. е. 6081 С. М., 582 Р. Х.) царь Маврикий усыновил Хозроя, царя персов, и послал к нему своего родственника Дометиана, епископа Мелитинского, вместе с Нарсесом, поручив сему последнему предводительство на войне» [Летопись византийца Феофана, 1884]. Епископ должен был исполнял роль посла самого высокого уровня. Однако при этом сложно сказать, какие полномочия и обязанности были возложены на епископа.

В случаях, когда появлялась непосредственная угроза пастве, епископы спешили встретиться с сасанидскими царями напрямую. Обычно это происходило во время персидских вторжений в границы Восточной Римской империи. Показателен пример, когда Хосров Ануширван в 540 г. уничтожил Сурон [Greatrex, Lieu, 2002], после чего за пленённых жителей города заступился епископ Сергиопольский Кандид, начавший переговоры с шахом. Переговоры закончились на том, что Кандид принял условия Хосрова, заключавшиеся в согласии освободить жителей за выкуп в 2 кентинария, после чего начал энергично собирать сумму по всей округе. В этой же кампании антиохийцев представляло посольство во главе с епископом Мегасом, предлагавшим шаху выкуп [Дмитриев, 2008]. Хосров настаивал на сумме в размере 10 кентинариев, что воспринималось антиохийцами как неподъемная сумма. Переговоры не привели ни к каким результатам, город был взят, а пленные жители города были угнаны в Персию. Мегас, поправ свое достоинство, просил Хосрова освободить пленных жителей Верои. 


\section{Заключение}

Описанные ситуации показывают, что епископы не просто брали на себя дипломатические миссии и выполняли роль послов, но и представляли свою общину в качестве практически самостоятельных лидеров. В сложных ситуациях, когда государственная власть исчезала, они олицетворяли находившуюся в их ведении религиозную и территориальную общину. Вероятнее всего, данные действия епископов не были согласованы с Константинополем и являлись проявлением самостоятельной инициативы, созданной критической ситуацией.

Путешествия епископов средиземноморского мира в Иран начались ещё во II в. и пик данного явления пришёлся на V век. Уже с последующего столетия связи начали распадаться и их значение резко упало, что можно объяснить внешнеполитическим переориентированием персидских царей и заметным замыканием несторианской общины на самой себе: начинает формироваться собственная, обособленная теология и культурная традиция несторианской церкви, все дальше отходящая от канонов и практик греческой церкви. C V в. римские епископы в Персии всё меньше занимались проповедью и больше политикой. В то же время в случае прямой опасности епископы сами вступали в переговоры с шахами, минуя получение на это одобрения со стороны своего императора. Однако даже во время наибольшей их активности самой крайней точкой, посещаемой сирийскими епископами, стал Гонди-Шапур в Эламе и западные районы Фарса. В основном, главной целью их были города Месопотамии и Ассирии.

Можно прийти к выводу, что чаще всего в пределы Персии из Восточно-Римской империи ехали сирийские священники - в первую очередь потому, что они не испытывали языковых и культурных препятствий на западной территории Сасанидской Персии, населённой, в основном, этнически близким им арамеоязычным населением (восточным сирийцам). Восточная Сирия стала культурным и дипломатическим мостом между Константинополем и Ктесифоном в этот период. Выступления представителей элиты христианской церкви в качестве дипломатов являлись традицией, характерной для всей истории христианства, особенно в период раннего Средневековья.

Вероятно, сирийские духовные лица, не связанные напрямую с государственной системой и обладавшие большим авторитетом, одновременно удаленные как от императорского, так и от шахского двора, стали самыми удобными фигурами в римскоперсидском дипломатическом процессе. Христианские общины на территории Сасанидского Ирана были достаточно влиятельными меньшинствами, и выбор в качестве посла христианского лидера был способом воздействовать на персидские элиты не только прямым, но и косвенным путём, воздействуя на общину иранских христиан. В определенные периоды истории христианское священство, имевшее большие связи, было уважаемо персидскими властями. В ряде ситуаций христианские епископы играли роль дипломатов и переговорщиков. Контакты при посредничестве сирийских священников были весьма частым явлением своего времени и происходили с достаточной регулярностью.

\section{Список литературы}

1. Дашков С.Б. 2008. Цари царей - Сасаниды. Иран III-VII вв. в легендах, исторических хрониках и современных исследованиях. М., СМИ-Азия, 356. дение, 259.

2. Дмитриев В.А. 2008. Всадники в сверкающей броне. СПб., Петербургское востокове-

3. Куликов А.О., Ващева И.Ю. 2018. Попытка усыновления Хосрова Ануширвана императором Юстином в контексте византийско-персидских отношений. Научные ведомости БелГУ. Серия История. Политология. Т. 45. 2: 227-234.

4. Левченко М.В. 1953. Агафий. О царствовании Юстиниана. М. - Л., изд-во Академии наук СССР, 232. 
5. Летопись византийца Феофана от Диоклетиана до царей Михаила и сына его Феофилакта. 1884. М., Университетская типография, 374.

6. Мишин Д.Е. 2014. Хосров I Ануширван (531-579), его эпоха и его жизнеописание и поучение в истории Мискавейха. М., ИВ РАН, 696.

7. Мишин Д.Е. 2017. История государства Лахмидов. М., ООО «Садра», 448.

8. Пигулевская Н.В. 2000. Сирийская средневековая историография. Исследования и переводы. СПб., Институт Востоковедения РАН, 760.

9. Пикин А.В. 2016. К вопросу о типологии посольских миссий в V веке. Научные ведомости БелГУ. Серия: История. Политология. Т. 38.8 (229): 38-43.

10. Пикин А.В. 2016. Политические миссии церковных деятелей в системе посольского взаимодействия конца IV - первой четверти VI века. Диссертация на соискание ученой степени кандидата исторических наук по специальности 07.00.03. Иваново, ИГУ, 195.

11. Пикин А.В. 2018. Так называемое завещание императора Аркадия и посольство Маруфы Майферкатского. Cursor Mundi: человек Античности, Средневековья и Возрождения. 10: 53-60.

12. Селезнев Н.Н. 2001. Ассирийская Церковь Востока. Исторический очерк. М., АЦВ, 105.

13. Селезнев Н.Н. 2005. Несторий и Церковь Востока. М., Путь, 111.

14. Сократ Схоластик. 1996. Церковная история. М., РОССПЭН, 368.

15. Чекалова А.А. 1993. Прокопий Кесарийский. Война с персами. Война с вандалами. Тайная история. М., Наука, 578.

16. Andrade N.J. 2013. Syrian identity in the Greco-Roman world. Cambridge University Press, 436.

17. Ball W. 2000. Rome in the East. The Transformation of an Empire. London, New York, Routledge, 544.

18. Bosworth C.E. 1999. History of al-Tabari. Vol. 5. The Sasanids, the Byzantines, the Lakhmids and Yemen. Albany, NY, State University of New York Press, 458.

19. Brock S. 2010. A fragment from a Syriac life of Marutha of Martyropolis. Analecta Bollandiana. Vol. 128. Bruxelles: 306-311.

20. Drijvers J.-W. 1965. Bardaisan. The Book of the Laws of Countries: A Dialogue on Fate by Bardaisan of Edessa. Assen, Van Gorcum \& Comp., 233.

21. Emami A. 1379 (2001). Ibn Miscawayh. Tajarib al-Umam. V. 1. Tehran: Soroush Press: 595 (in Arabian).

22. Gillett A. 2003. Envoys and Political Communication in the Late Antique West, 411-533. Cambridge, Cambridge University Press, 335.

23. Greatrex G., Lieu S.N.C. 2002. Roman Eastern Frontier and the Persian Wars. Part II. A. D. 363-630. A Narrative Sourcebook. London, New York, Routledge, 406.

24. Harrak A. 2005. The Acts of Mār Mārī the Apostle. Writings from the Greco-Roman World, no. 11. Atlanta, Society of Biblical Lit., 110.

25. Matthew P.C. 2009. The Two Eyes of the Earth: Art and Ritual of Kingship Between Rome and Sasanian Iran. Berkley, Los Angeles, London, University of California Press, 456.

26. Patrologia Graeca, T. 67: Socrates, Historia Ecclesiastica; Sozomen, Historia Ecclesiastica. 1859. Paris, ex. et ven. apud J.-P. Migne (ed.), 30-842.

27. Patrologia Orientalis. Tomus 04: Duval R., Wessely C., Mgr. Scher A., Perier J., Nau F., Bousquet J., Goodspeed E.-J., Crum W.E. 1908. Paris, Librairie de Paris, Firmin-Didot et C., ImprimeursÉditeurs: 213-313.

28. Patrologia Orientalis. Tomus 05: Evetts B., Mgr. Scher A., Dib P., Bayan G., Max de Saxe (le prince S.A.R.), Vasiliev A., Leroy L., Nau F. 1910. Paris, Librairie de Paris, Firmin-Didot et C., Imprimeurs-Éditeurs: 217-344.

29. Patrologia Orientalis. Tomus 07: Mgr. Scher A., Guidi I., Vasiliev A.A., Brooks E.-W. 1911. Paris., Librairie de Paris, Firmin-Didot et C., Imprimeurs-Éditeurs: 84-203.

30. Patrologia Orientalis. Tomus 13: Grebaut S., Nau F., Asin M. et Palacios, S.G. Mgr. Addai Sher, Griveau Robert, Pereira E. 1919. Paris., Librairie de Paris, Firmin-Didot et C., Imprimeurs-Éditeurs, 333-639.

31. Synodicon Orientale. 1902. Paris, Imprimerie Nationale, 698.

32. Wood Ph. 2013. The Chronicle of Seert. Christian Historical Imagination in Late Antique Iraq. Oxford: Oxford University Press, 320. 


\section{References}

1. Dashkov S.B. 2008. Tsari tsarey - Sasanidy. Iran III-VII vv. v legendakh, istoricheskikh khronikakh i sovremennykh issledovaniyakh [Kings of kings - Sassanids. Iran III-VII centuries in legends, historical chronicles and modern studies]. M., SMI-Aziya, 356.

2. Dmitriyev V.A. 2008. Vsadniki v sverkayushchey brone [Riders in Glittering Armor]. SPb, Peterburgskoye vostokovedeniye, 259.

3. Kulikov A.O., Vashcheva I.Yu. 2018. Popytka usynovleniya Khosrova Anushirvana imperatorom Yustinom v kontekste vizantiysko-persidskikh otnosheniy [Attempt to adopt Khosrov Anushirvan by Emperor Justin in the context of Byzantine-Persian relations]. Nauchnye vedomosti BelGU [Scientific Bulletin of BelSU]. Seriya Istoriya. Politologiya. T. 45. 2: 227-234.

4. Levchenko M.V. 1953. Agafiy. O tsarstvovanii Yustiniana [Agathius. On the reign of Justinian]. M. - L., izd-vo Akademii nauk SSSR, 232.

5. Letopis' vizantiytsa Feofana ot Diokletiana do tsarey Mikhaila i syna yego Feofilakta [Chronicle of the Byzantine Theophanes from Diocletian to tsars Michael and his son Theophylact]. 1884. M., Universitetskaya tipografiya, 374.

6. Mishin D.Ye. 2014. Khosrov I Anushirvan (531-579), yego epokha i yego zhizneopisaniye i poucheniye v istorii Miskaveykha [Khosrov I Anushirvan (531-579), his era and his biography and teaching in the history of Miskaveikh]. M., IV RAN, 696.

7. Mishin D.Ye. 2017. Istoriya gosudarstva Lakhmidov [History of the Lakhmids state]. M., OOO «Sadra», 448.

8. Pigulevskaya N.V. 2000. Siriyskaya srednevekovaya istoriografiya. Issledovaniya i perevody [Syrian medieval historiography. Research and translations]. SPb., Institut Vostokovedeniya RAN, 760.

9. Pikin A.V. 2016. K voprosu o tipologii posol'skikh missiy v V veke [On the question of the typology of embassy missions in the 5th century]. Nauchnyye vedomosti Belgorodskogo gosudarstvennogo universiteta [Scientific Bulletin of BelSU]. Seriya: Istoriya. Politologiya. T. 38.8 (229): 38-43.

10. Pikin A.V. 2016. Politicheskiye missii tserkovnykh deyateley v sisteme posol'skogo vzaimodeystviya kontsa IV - pervoy chetverti VI veka [Political missions of church leaders in the system of ambassadorial interaction at the end of the 4th - first quarter of the 6th century]. Dissertatsiya na soiskaniye uchenoy stepeni kandidata istoricheskikh nauk po spetsial'nosti 07.00.03 [Dissertation for the degree of candidate of historical sciences in specialty 07.00.03]. Ivanovo, IGU, 195.

11. Pikin A.V. 2018. Tak nazyvayemoye zaveshchaniye imperatora Arkadiya i posol'stvo Marufy Mayferkatskogo [The so-called testament of Emperor Arcadius and the embassy of Marufa of Mayferkat]. Cursor Mundi: chelovek Antichnosti, Srednevekov'ya i Vozrozhdeniya [Cursor Mundi: a man of Antiquity, Medieval and Renaissance]. 10: 53-60.

12. Seleznev N.N. 2001. Assiriyskaya Tserkov' Vostoka. Istoricheskiy ocherk [Assyrian Church of the East. Historical sketch]. M., ATSV, 105. Put', 111.

13. Seleznev N.N. 2005. Nestoriy i Tserkov' Vostoka [Nestorius and the Church of the East]. M.,

14. Sokrat Skholastik [Socrates Scholastic]. 1996. Tserkovnaya istoriya [Church history]. M., ROSSPEN, 368.

15. Chekalova A.A. 1993. Prokopiy Kesariyskiy. Voyna s persami. Voyna s vandalami. Taynaya istoriya [Procopius of Caesarea. War with the Persians. War with the vandals. Secret history]. M., Nauka, 578.

16. Andrade N.J. 2013. Syrian identity in the Greco-Roman world. Cambridge University Press, 436.

17. Ball W. 2000. Rome in the East. The Transformation of an Empire. London, New York, Routledge, 544.

18. Bosworth C.E. 1999. History of al-Tabari. Vol. 5. The Sasanids, the Byzantines, the Lakhmids and Yemen. Albany, NY, State University of New York Press, 458.

19. Brock S. 2010. A fragment from a Syriac life of Marutha of Martyropolis. Analecta Bollandiana. Vol. 128. Bruxelles: 306-311.

20. Drijvers J.-W. 1965. Bardaisan. The Book of the Laws of Countries: A Dialogue on Fate by Bardaisan of Edessa. Assen, Van Gorcum \& Comp., 233.

21. Emami A. 1379 (2001). Ibn Miscawayh. Tajarib al-Umam. V. 1. Tehran: Soroush Press: 595 (in Arabian). 
22. Gillett A. 2003. Envoys and Political Communication in the Late Antique West, 411-533. Cambridge, Cambridge University Press, 335.

23. Greatrex G., Lieu S.N.C. 2002. Roman Eastern Frontier and the Persian Wars. Part II. A. D. 363-630. A Narrative Sourcebook. London, New York, Routledge, 406.

24. Harrak A. 2005. The Acts of Mār Mārī the Apostle. Writings from the Greco-Roman World, no. 11. Atlanta, Society of Biblical Lit., 110.

25. Matthew P.C. 2009. The Two Eyes of the Earth: Art and Ritual of Kingship Between Rome and Sasanian Iran. Berkley, Los Angeles, London, University of California Press, 456.

26. Patrologia Graeca, T. 67: Socrates, Historia Ecclesiastica; Sozomen, Historia Ecclesiastica. 1859. Paris, ex. et ven. apud J.-P. Migne (ed.), 30-842.

27. Patrologia Orientalis. Tomus 04: Duval R., Wessely C., Mgr. Scher A., Perier J., Nau F., Bousquet J., Goodspeed E.-J., Crum W.E. 1908. Paris, Librairie de Paris, Firmin-Didot et C., ImprimeursÉditeurs: 213-313.

28. Patrologia Orientalis. Tomus 05: Evetts B., Mgr. Scher A., Dib P., Bayan G., Max de Saxe (le prince S.A.R.), Vasiliev A., Leroy L., Nau F. 1910. Paris, Librairie de Paris, Firmin-Didot et C., Imprimeurs-Éditeurs: 217-344.

29. Patrologia Orientalis. Tomus 07: Mgr. Scher A., Guidi I., Vasiliev A.-A., Brooks E.-W. 1911. Paris., Librairie de Paris, Firmin-Didot et C., Imprimeurs-Éditeurs: 84-203.

30. Patrologia Orientalis. Tomus 13: Grebaut S., Nau F., Asin M. et Palacios, S.G. Mgr. Addai Sher, Griveau Robert, Pereira E. 1919. Paris., Librairie de Paris, Firmin-Didot et C., Imprimeurs-Éditeurs, 333-639.

31. Synodicon Orientale. 1902. Paris, Imprimerie Nationale, 698.

32. Wood Ph. 2013. The Chronicle of Seert. Christian Historical Imagination in Late Antique Iraq. Oxford: Oxford University Press, 320.

\section{ИНФОРМАЦИЯ ОБ АВТОРЕ}

Куликов Александр Олегович, аспирант кафедры средневековых цивилизаций Национального исследовательского Нижегородского государственного университета им. И.И Лобачевского, г. Нижний Новгород, Россия

\section{INFORMATION ABOUT THE AUTHOR}

Alexandr O. Kulikov, postgraduate student of the Department of Medieval Civilizations of the National Research Nizhegorodskiy State University named after I.I. Lobachevsky, Nizhny Novgorod, Russia 